\title{
Progress in practical hydrogen production and utilisation in East Asia
}

\author{
Pradipto Suwidji ${ }^{1}$, Hoi Ying Chung ${ }^{1}$, Yun Hau $\mathrm{Ng}^{1,2}$ \\ ${ }^{1}$ School of Energy and Environment, City University of Hong Kong, Hong Kong, People's Republic of China \\ ${ }^{2}$ City University of Hong Kong Shenzhen Research Institute, Shenzhen Hi-Tech Industrial Park, Shenzhen, People's Republic of China
}

\begin{abstract}
Development of hydrogen utilisation for energy applications has seen promising innovation towards the future prospect of clean and sustainable energy, benefitting various aspects of environmental, social, industrial and energy security. In the APEC region, several economies, such as the USA, China, Australia, Japan and South Korea, have shown interest in the development of hydrogen technology for energy applications. These economies have been devoting effort towards research and development programmes, pilot projects and, up to a certain point, implementing it in their communities. In addition, these economies each have their own tailored hydrogen roadmap or strategy, ensuring a smoother path towards hydrogen development. In this mini-review, we analysed the approaches of three selected economies in the East Asia region towards hydrogen technology, namely China, Japan and South Korea. Each of these economies have their own strategies and priorities towards the application, production and future development of hydrogen technology. This review also analyses the future possibilities for the integration of hydrogen technology into various sectors, as well as various constraints faced by each economy. Therefore, the review might serve as a valuable reference towards the feasibility of future hydrogen technology development in the East Asia and APEC region.
\end{abstract}

KEYWORDS Hydrogen production; hydrogen technology; clean energy.

CONTACT Yun Hau Ng yunhau.ng@cityu.edu.hk

Received 24 November 2020

\section{Introduction}

Hydrogen has attracted the interest of various governments around the world as an alternative source of cleaner and more environmentally friendly energy. This is partly triggered by the suitability of hydrogen use in the hydrogen fuel cell as a method of generating electricity, with only water and heat as by-products. This affords a minimum level of emissions in the energy utilisation process. To date, hydrogen is dominantly produced from fossil fuels (natural gas and coal), while renewable energy sources and other various methods offer potential routes (Sichao et al., 2018), as shown in the table below.

The products of hydrogen can be classified into three main categories depending on the generation method. Grey Hydrogen is a type of hydrogen produced from fossil fuels that involves combustion of natural gas or coal with methods such as steam methane reforming (SMR). However, no carbon capture utilisation or storage (CCUS) is done in Grey Hydrogen. Blue Hydrogen is produced from fossil fuels with carbon-neutral status as CCUS technology is applied. Green Hydrogen is relatively cleaner and produced by electrolysis of water that does not release carbon emissions, provided that the electricity used to power the electrolysis process is generated by renewable energy.

As of 2018, global hydrogen production has been stagnant at a level of approximately 55 million tonnes or the equivalent of 6600 PJ per year (ACIL Allen Consulting, 2020). In terms of low-carbon hydrogen production, it is still relatively low as of 2019 , with only about $0.36 \mathrm{Mt}$ of hydrogen produced, using electrolysis or integration of conventional technologies with carbon capture and utilisation or storage (CCUS).

Table 1. Hydrogen production technologies method (Sichao et al., 2018 ; International Energy Agency, 2015).

\begin{tabular}{|l|l|l|l|l|}
\hline & Status & \multicolumn{1}{|c|}{$\begin{array}{c}\text { Process } \\
\text { stability }\end{array}$} & \multicolumn{1}{|c|}{$\begin{array}{c}\text { COO } \\
\text { emissions }\end{array}$} & \multicolumn{1}{|c|}{ Cost } \\
\hline $\begin{array}{l}\text { By-products of } \\
\text { industries }\end{array}$ & Practical & $\begin{array}{l}\text { Depends } \\
\text { on primary } \\
\text { products }\end{array}$ & $\begin{array}{l}\text { Depends } \\
\text { on primary } \\
\text { products }\end{array}$ & $\begin{array}{l}\text { Depends } \\
\text { on primary } \\
\text { products }\end{array}$ \\
\hline Fossil fuel reforming & Practical & Stable & $\begin{array}{l}\text { Yes, unless } \\
\text { there is CCS }\end{array}$ & Relatively low \\
\hline $\begin{array}{l}\text { Electrolysis (Thermal } \\
\text { power) }\end{array}$ & Practical & Stable & $\begin{array}{l}\text { Yes, unless } \\
\text { there is CCS }\end{array}$ & Relatively low \\
\hline $\begin{array}{l}\text { Electrolysis } \\
\text { (Renewable power) }\end{array}$ & Practical & $\begin{array}{l}\text { Variable } \\
\text { depending on } \\
\text { energy source }\end{array}$ & No & Decreasing \\
\hline Biomass pyrolysis & R\&D & $\begin{array}{l}\text { Variable } \\
\text { depending on } \\
\text { area }\end{array}$ & No & Relatively high \\
\hline $\begin{array}{l}\text { Thermochemical } \\
\text { water splitting }\end{array}$ & R\&D & Stable & $\begin{array}{l}\text { Depends on } \\
\text { heat source }\end{array}$ & N/A \\
\hline $\begin{array}{l}\text { Hydrogen-producing } \\
\text { catalyst }\end{array}$ & R\&D & Variable & No & N/A \\
\hline
\end{tabular}

Low-carbon hydrogen production technologies using electrolysis can be based on technologies such as proton exchange membrane (PEM) electrolysis, solid oxide electrolysis cells (SOEC) and alkaline electrolysis.

Alkaline electrolysis splits water into hydrogen and oxygen using electrical energy. The reaction involves the reduction of water to hydrogen at the cathode, and the oxidation of hydroxide ions or water to oxygen at the anode. This system uses concentrated liquid alkaline as the 
electrolyte and utilises a separator with gas-impermeable characteristics to reduce the tendency of output gases to mix. Recent developments in electrodes have seen the use of non-noble metals like nickel and decorated with an electrocatalytic coating. The system operates at temperatures of approximately $50-80^{\circ} \mathrm{C}$, with pressure up to 30 bar. Nominal stack efficiency at approximately $70 \%$ and stack capacity of around $6 \mathrm{MW}$ can be achieved (Brauns and Turek, 2020). The alkaline electrolyser is known to have a higher lifetime with affordable maintenance and lower investment costs compared to a proton exchange membrane (PEM) electrolyser (Brauns and Turek, 2020).

Proton exchange membrane (PEM) electrolysis is another type of electrolyser utilising solid polymer as an electrolyte. Typically, the electrocatalysts would be noble metals such as platinum and iridium oxide. The system operates at temperatures of approximately $50-80^{\circ} \mathrm{C}$, with pressure up to 30 bar. Nominal stack efficiency at approximately $70 \%$ and stack capacity of around $2 \mathrm{MW}$ can be achieved (Brauns and Turek, 2020). The PEM system has been known to have a greater advantage in its shorter start-up time compared to an alkaline electrolysis system (Brauns and Turek, 2020).

As alkaline electrolysers and PEM electrolysers have been implemented for hydrogen production, solid oxide electrolysis cells (SOEC) have been shown to be a promising technology that is currently going through intense development at various institutions worldwide. The system is also known as steam electrolysis due to its process involving gaseous water conversion to hydrogen and oxygen at temperatures between $700-900^{\circ} \mathrm{C}$ (Brauns and Turek, 2020). Theoretically, the stack efficiency is at approximately $100 \%$ as they are affected by positive thermodynamic effects on power consumption at such hightemperature operation (Brauns and Turek, 2020). Given the high temperatures of operation, this system will require more fuel for its heat source. In terms of stack capacity, current developments have only reached up to $10 \mathrm{~kW}$, which is much lower than alkaline and PEM electrolysers (Brauns and Turek, 2020).

According to reports from the International Energy Agency (IEA) (Bermudez and Hasegawa, 2020), the trend of hydrogen production using low-carbon technologies, though continuing to grow slowly, are relatively stagnant as of 2019, with $0.36 \mathrm{Mt}$ of hydrogen produced, despite high targets and projections to be made in the following years. Yet, hydrogen demand has increased in recent decades. The demand growth analysed by the IEA shows that hydrogen is mainly utilised for ammonia production and industrial oil refineries, together with other industrial processes such as methanol and steel production (International Energy Agency, 2019). Currently, there are initial uses of hydrogen in transportation sectors such as fuel cell vehicles (FCVs), blending into gas grids in metropolitan cities. In terms of power generation, hydrogen has also started to play important roles elsewhere, including the hydrogen-powered power plant, and utilisation of hydrogen and ammonia in natural gas power plants to enhance the flexibility of power systems. Ammonia produced by using hydrogen can also be used in coal-fired power plants as a starter fuel mix to reduce emissions.

The development of hydrogen production and usage has recently become a key point in the development of many countries. Indeed, development of hydrogen has been included in a number of countries' plans for future research and development projects, or even embedded in their strategic economic plans. This review will focus more on the countries in the Asia-Pacific Economic Cooperation (APEC) Region, typically in East Asia.

The APEC Region, made up of 21 countries in the Asia-Pacific Region, considers hydrogen to be a very important issue because the region has abundant fossil fuels and renewable energy sources for hydrogen production. The efforts in reducing $\mathrm{CO}_{2}$ emissions and improving the region's energy security have also made hydrogen a potential solution (Sichao et al., 2018). Research conducted by the Asia Pacific Energy Research Centre (APERC) shows that the demand for hydrogen energy use in the APEC region in 2050 would be 352 Mtoe, equivalent to $7 \%$ of the primary energy supply in 2018 . In terms of the reduction of $\mathrm{CO}_{2}$ emissions, it is forecasted that it will help to reduce $1.2 \mathrm{Gt}$ of $\mathrm{CO}_{2}$ emitted, equivalent to $6 \%$ of the 2018 data. On a macro scale, hydrogen can be a candidate to improve the region's energy security as countries with massive reserves of fossil fuels and abundant renewable energy sources (e.g. the USA, Canada, Australia, New Zealand, Mexico, Indonesia and Chile) can make hydrogen an export commodity. Therefore, this may have influence in maintaining a balance of supply and demand of hydrogen for future utilisation in the APEC region, as well as aiming towards more prosperous economic growth.

Seeing the great potential hydrogen has to offer, a number of important issues related to hydrogen development will likely be rigorously considered by policymakers, covering the life cycle of hydrogen development to include acquisition of raw materials, production processes, consumption, research and development, economical impacts, environmental impacts and safety standards. In this report, we will be discussing hydrogen developments in the APEC economies of China, Japan and South Korea. Due to the varying amounts of accessible information, the level of coverage will vary from country to country.

\section{Hydrogen Development in East Asia}

\subsection{China}

China is currently the largest producer of hydrogen in the world, generating up to 20 million tonnes of annual hydrogen production, making up approximately one third 
of global hydrogen production (Yue and Wang, 2020). However, the predominant production method currently is the coal-based steam methane reforming (SMR) method, with electrolysis methods of producing hydrogen taking only up to $3 \%$ of its production (Yue and Wang, 2020). Hydrogen production from coal remains the most affordable option, $30 \%$ cheaper than natural gas as a source (de Blasio and Pflugmann, 2020). Hydrogen in China is produced by more than 1000 gasifiers countrywide, which makes up 5\% of China's total coal consumption (de Blasio and Pflugmann, 2020). Since 2010, China is the largest producer and consumer of this energy (Holland Innovation Network, 2019). China is also leading in terms of renewable energy development and has become one of the largest producers of solar and wind energy. With the rise of renewable energy development in China, hydrogen can serve as an energy source to produce electricity and at the same time, hydrogen is planned to act as a reserve source of energy generation at times when renewable energy production is not meeting demand levels. Hydrogen is currently used mostly for industrial and chemical processes such as ammonia production, with China accounting for $30 \%$ of global ammonia production (U.S Geological Survey, 2020).

Hydrogen is indeed part of China's strategy towards its initiative in tackling climate change. This is mainly due to its carbon-free emissions when utilised in combustion processes, as it only produces water, with the combustion reaction of:

$$
2 \mathrm{H}_{2}+\mathrm{O}_{2} \rightarrow 2 \mathrm{H}_{2} \mathrm{O}
$$

However, it is also worth noting that the cleanest form of hydrogen is always the one being produced by an electrolysis process powered by renewable energy sources. Hydrogen is very advantageous in terms of being a storage energy as mentioned above, serving as reserve stored energy to support electricity production if renewable energy-based electricity production is not meeting demand. Also, it can power fuel cell systems, whether in stationary usage such as for buildings or industrial areas, or mobile applications in FCVs.

Hydrogen technological development is included in the Made in China 2025 Initiative, China's 2015 national strategy on leveraging its manufacturing sector issued by Premier Li Keqiang and the cabinet. This included FCV production goals for 2025, as well as the boosting of its overall performance to compete with traditional gasolinepowered vehicles and electric vehicles in the market. Scaling up infrastructures for hydrogen production demands and refueling stations are also within the initiative. Overall, it is one of China's targets in terms of future projects for technological advancements, which can be integrated into various sectors in its domestic market, as well as overseeing possible future export opportunities, to position the country at the leading edge of global competitiveness. In terms of geopolitical perspective, China puts renewable hydrogen as a key component in the Belt \& Road Initiative, as a symbol of China's technological advancement and its contribution towards fighting climate change (de Blasio and Pflugmann, 2020).

\subsubsection{Hydrogen Applications in China}

In terms of hydrogen applications, China has been engaged in several developmental projects, both pilot projects and commercial applications. Indeed, one reason for China's focus on hydrogen is to leverage its technological advancement and showcase its application. Hydrogen-related projects and developments have been rapidly progressing in China, especially in the transportation sector. One apparent example is the Tangshan Tram in Tangshan City, Hebei. The tram project was completed in October 2017, powered by the fuel cell engines of Ballard FCveloCityTM and trainsets produced by the CRRC Tangshan Railway Vehicle Company (TRC), China's pioneering railway company (Ballard Power, 2020). Further development includes the implementation of five hydrogenpowered trams on the Gaoming Tram Line that is currently operating in Foshan, Guangdong, since November 2019 (Ballard Power, 2020). Ballard Power System is responsible for implementing its FCveloCityTM fuel cell modules in the trainsets manufactured by CRRC Qingdao. With the first phase completed in November 2019, developments for the second phase are currently ongoing and scheduled to be finished by early 2021 .

The application of hydrogen-powered buses dates back to the 2008 Beijing Olympics, where buses were demonstrated for their technological readiness and performance as means of public transportation (Society of Automotive Engineers of China, no date). Since then, hydrogen-powered buses have been demonstrated in various events such as the 2010 Shanghai Expo. Indeed, these demonstrations in major international events have become one of China's key approaches to highlight their technology, in order to increase international awareness. Zhengzhou city replaced its fleet of public buses with fuel cell buses in June 2020. Various cities across China such as Beijing, Shanghai, Nanjing, Qingdao and others have also been replacing their public bus fleets with the newly introduced hydrogen-powered buses (Holland Innovation Network, 2019). Other than buses, hydrogen-powered trucks have also been introduced on the road. JD.com, the e-commerce startup company in China, has operated 500 hydrogen-powered trucks in Shanghai for their logistics operation since July 2018. These trucks are supported by two hydrogen refueling stations in the Jiading district of Shanghai. The hydrogen refueling station provides a retail price for hydrogen at $40 \mathrm{RMB} / \mathrm{kg}$ (Holland Innovation Network, 2019). According to JD.com, the trucks can travel up to $300 \mathrm{~km}$ with a full tank load, transporting up to 3.5 tonnes of cargo, marking it as one of JD.com's initiatives on carbon-free distribution processes as these trucks only emit 
pure water as their emission (JD Corporate Blog, 2018). Other than that, the startup company, STNE (Shanghai Sinotran New Energy Automobile Operation CO., LTD.), signed a partnership agreement in 2018 to boost the development of hydrogen truck utilisation in China. As of the 2018 agreement, STNE operated 500 hydrogenpowered trucks and one hydrogen refueling station, with continuous plans on expansion after the signed agreement with Air Liquide, a leading company for industrial gases and technologies (Air Liquide, 2018). Air Liquide will play a role in providing technical expertise on the end-to-end hydrogen supply chain, from the production stage up to the end user.

Chinese companies have also been active in terms of research and development of fuel cell engines. Two examples are Re-Fire and SinoHytec, with each of them having foreign partnerships such as Ballard and Hydrogenics respectively. They are the main suppliers of fuel cell engines to the local Chinese automobile industry that produces FCVs, which includes hydrogen-powered cars, buses, trucks and various road transportations. As of 2018 , Re-Fire dominates more than $50 \%$ of fuel cell engines sold in the Chinese market and also has a subsidiary company, Shenzhen Suyun Technology Co., Ltd, which has a technological platform to perform real-time data tracking of the vehicle components and powertrain capabilities of all Re-Fire installed vehicles on the road (Holland Innovation Network, 2019). Both Re-Fire and SinoHytec have key partnership agreements with automobile manufacturers and local governments across China, to boost research and development projects of hydrogen-powered vehicles, as well as to promote the expansion of various pilot projects and technical demonstrations in the Chinese market.

In terms of local hydrogen-powered bus production, the Yunfu project in Foshan, Guangdong is one of the most notable development projects in China. The project was inspired by a visit by a group of Chinese delegates to London to observe the Clean Hydrogen in European Cities project (CHIC project) (Liu et al., 2018). This was followed by the formation of the company Synergy, which signed an agreement with Ballard Power Systems, a Canadian company specialising in PEM fuel cell products for industries, to work on the commercial assembly of Ballard-licensed fuel cells in Yunfu Industrial Park, Foshan, Guangdong. The Yunfu Industrial Park possesses the capacity to produce 5000 buses annually (Figure 1), a fuel cell stack production facility, a fuel cell module assembly line, a hydrogen refueling station and a research centre (Liu et al., 2018). These facilities were completed in July 2017. As of 2018, it was claimed that bus production in Foshan had overtaken the total EU, Japanese and US hydrogenpowered bus production combined.

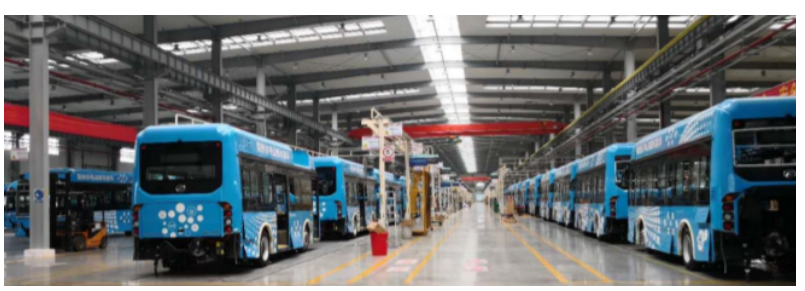

Figure 1. Hydrogen-powered bus production facility in Yunfu Industrial Park (Liu et al., 2018).

With this capacity for hydrogen-powered bus production, the demand for hydrogen refueling stations is also increasing. As of 2018, there are 20 hydrogen refueling stations in China, as seen in Table 2 below. From Table 2, we can see that most of the 20 operating hydrogen refueling stations were built after 2015. Further construction of hydrogen refueling stations is now underway, in keeping with the rise in hydrogen-powered bus production in China since its first demonstration in Beijing in 2006 (Holland Innovation Network, 2018). Numbers vary, but according to one source, at last count there were 66 hydrogen refueling stations in China, of which 46 are currently operational (Jiang et al., 2020). Despite the different numbers given by various sources, we can see a clear trend in the deployment of hydrogen refueling stations in Figure 2 below.

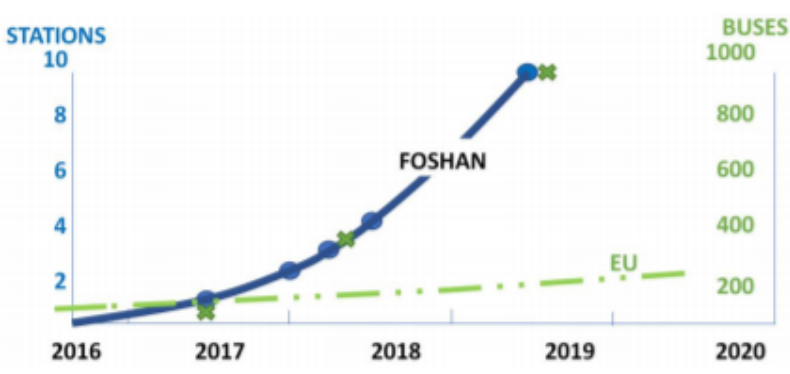

Figure 2. Trend in deployment of hydrogen refueling stations in Foshan compared with the EU (Liu et al.,2018).

From a micro-scale analysis based on the graph above, we can see that the rate of deployment of hydrogenrefueling stations in the city of Foshan trends higher than in the EU. Deployment is increasing in accordance with the increasing number of hydrogen buses produced and deployed in Foshan since the 2008 Beijing Olympics and the 2010 Shanghai Expo, where, as previously mentioned, they were demonstrated for international exposure. The Volkswagen (VW) Passat Lingyu FCV is China's first locally produced hydrogen-powered car; other locally developed hydrogen cars include the FAW Pentium, Changan Z-Shine and Chery Eastar. However, hydrogenpowered passenger cars usage in China is still in its early stages as compared to other nations. According to IPHE, there are only 50 operational hydrogen-powered cars in China as of 2020. Hydrogen-powered buses are the dominant mode of hydrogen-powered transportation 
Table 2. Detailed record of hydrogen refueling stations in China as of 2018 (Liu et al., 2018).

\begin{tabular}{|c|c|c|c|c|c|c|c|c|}
\hline No. & City & Name & Category & Finish year & $\begin{array}{c}\mathrm{H}_{2} \text { storage capacity } \\
\text { \& pressure }\end{array}$ & Filling capacity & $\begin{array}{c}\text { Filling } \\
\text { pressure }\end{array}$ & State \\
\hline 1 & Beijing & Yongfeng & Stationary & 2006 & $165 \mathrm{~kg}, 45 \mathrm{MPa}$ & $200 \mathrm{~kg} /$ day & $35 \mathrm{MPa}$ & In Use \\
\hline 2 & Shanghai & Anting & Stationary & 2007 & $165 \mathrm{~kg}, 45 \mathrm{MPa}$ & $200 \mathrm{~kg} /$ day & $35 \mathrm{MPa}$ & In Use \\
\hline 3 & Zhangzhou & Yutong & Stationary & 2015 & $165 \mathrm{~kg}, 45 \mathrm{MPa}$ & $250+1000 \mathrm{~kg} /$ day & $35 \mathrm{MPa}$ & In Use \\
\hline 4 & Yunfu & Synergy & Stationary & 2016 & $165 \mathrm{~kg}, 45 \mathrm{MPa}$ & $300 \mathrm{~kg} /$ day & $35 \mathrm{MPa}$ & In Use \\
\hline 5 & Dalian & Tongji-Sunrise & Stationary & 2016 & $90 \mathrm{MPa}$ & $20 \mathrm{~kg} /$ day & $70 \mathrm{MPa}$ & In Use \\
\hline 6 & Foshan & Nanhai Ruihui & Stationary & 2017 & $234 \mathrm{~kg}, 45 \mathrm{MPa}$ & $350 \mathrm{~kg} /$ day & $35 \mathrm{MPa}$ & In Use \\
\hline 7 & Shanghai & $\begin{array}{l}\text { Shanghai } \\
\text { Edrive }\end{array}$ & Container & 2017 & $165 \mathrm{~kg}, 45 \mathrm{MPa}$ & $500 \mathrm{~kg} /$ day & $35 \mathrm{MPa}$ & In Use \\
\hline 8 & Zhongshan & Broadoceam & Container & 2017 & - & $500 \mathrm{~kg} /$ day & $35 \mathrm{MPa}$ & In Use \\
\hline 9 & Changshu & Toyota & Stationary & 2017 & $90 \mathrm{MPa}$ & - & $70 \mathrm{MPa}$ & In Use \\
\hline 10 & Nantong & Bing Energy & Temporary & 2017 & $150 \mathrm{~kg}, 45 \mathrm{Mpa}$ & $60 \mathrm{~kg} /$ day & $35 \mathrm{MPa}$ & In Use \\
\hline 11 & Shanghai & Godpower & Temporary & 2017 & - & - & $35 \mathrm{MPa}$ & In Use \\
\hline 12 & Jiaxing & Aideman & Temporary & 2017 & - & - & $35 \mathrm{MPa}$ & In Use \\
\hline 13 & Foshan & Sanshui & Temporary & 2017 & - & $100 \mathrm{~kg} /$ day & $35 \mathrm{MPa}$ & In Use \\
\hline 14 & Shiyan & Dongfeng & Container & 2018 & - & $500 \mathrm{~kg} /$ day & $35 \mathrm{MPa}$ & In Use \\
\hline 15 & Chengdu & Jinxing & Container & 2018 & $234 \mathrm{~kg}, 45 \mathrm{MPa}$ & $500 \mathrm{~kg} /$ day & $35 \mathrm{MPa}$ & In Use \\
\hline 16 & Shanghai & Jiangqiao & Container & 2018 & $464 \mathrm{~kg}, 45 \mathrm{Mpa}$ & $750 \mathrm{~kg} /$ day & $35 \mathrm{MPa}$ & In Use \\
\hline 17 & Wuhan & Zhongji & Stationary & 2018 & - & $200 \mathrm{~kg} /$ day & $35 \mathrm{MPa}$ & In Use \\
\hline 18 & Xinbin & Muhai & Container & 2018 & - & $450 \mathrm{~kg} /$ day & $35 \mathrm{MPa}$ & In Use \\
\hline 19 & Zhangjiakou & Haiboer & Stationary & 2018 & - & $1350 \mathrm{~kg} /$ day & $35 \mathrm{MPa}$ & In Use \\
\hline 20 & Yunfu & Luoding & Stationary & 2018 & - & $500 \mathrm{~kg} /$ day & $35 \mathrm{MPa}$ & In Use \\
\hline
\end{tabular}

*Where there is no available information, cases have been marked with “_““

produced and sold in China. In terms of total sale volume of hydrogen-powered transportation of FCVs, which includes buses and cars, the growth of sales for the past five years is shown in Figure 3 below.

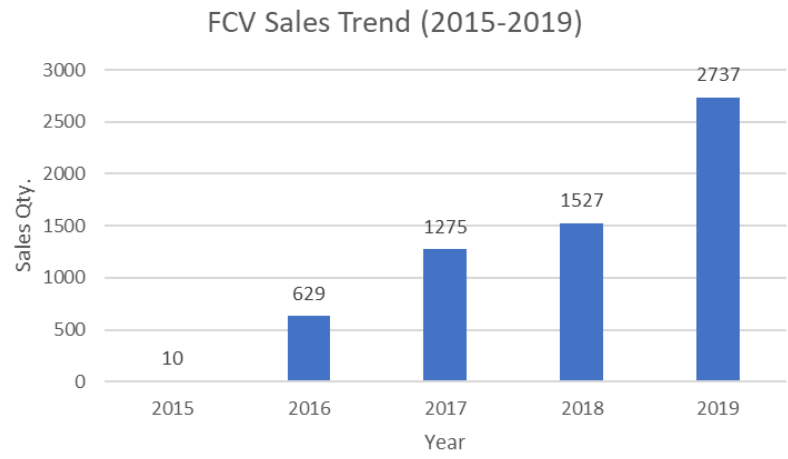

Figure 3. Sales growth of hydrogen-powered transportation of FCVs (buses and cars) (Jiang et al., 2020).

Research and development on the possibilities of utilising hydrogen in the shipping industry is also taking place in China. The 712th Research Institute of China Shipbuilding Industry Corporation (CSIC) is actively engaged in the research and development of fuel cells for use in the shipping industry. The China State Shipbuilding Corporation (CSSC) in Guangzhou is also performing research and development for fuel cell hydrogen-powered ships. However, this field is still in its infancy (Holland
Innovation Network, 2018).

While the majority of hydrogen utilisation is focused towards the transportation sector, there are also recent developments in other sectors, though most are still in the developmental and research phase, or trial projects. In Sichuan province, there have been developments recently by the Tsinghua-Sichuan Energy Internet Research Institute in Chengdu in blending hydrogen into local gas grids (Holland Innovation Network, 2018). This is a fundamental research programme which involves laboratory tests blending up to $17 \%$ hydrogen into the grids. There are plans to apply the project towards pilot projects in future to find solutions to phase out the commonly used coal-based boilers and move to cleaner gas-based boilers. By blending hydrogen into the gas grids, it is hoped that this will reduce reliance on natural gas sources, whilst maintaining good efficiency and performance.

A hydrogen fuel cell power plant was built at the Ynnovate Sanzheng Fine Chemicals Company in Liaoning province back in 2016 with the assistance of Dutch companies, specifically a two MW PEM fuel cell power plant to generate electricity using by-product hydrogen (Holland Innovation Network, 2018). Indeed, the plant supports up to $20 \%$ of Ynnovate's power consumption for its production sector. This is a form of stationary hydrogen power. Although fuel cell manufacturers and developers in China are eager to develop such technologies, the cost of installation for use in various industries is still considered to be high. 


\subsubsection{Government support and strategic planning}

The Chinese government is supportive in implementing hydrogen technologies for utilisation in the country, with the majority in the transportation sector. The growth and development of hydrogen technology in China is fueled by its ambition to be a technological powerhouse and strengthen its global competitiveness, to mitigate climate change and produce hydrogen for energy security purposes. Hydrogen and fuel cells have been research interests since the 1950s for space programmes, and for commercial applications since the late 1980s, as part of the National High Technology Research and Development programme known as 863 . Subsequently, it was included in the 973 research programme in 1997 to boost research on hydrogen and fuel cell technologies. The timeline of government financial support towards hydrogen in the Fiveyear Plans is as follows:

(1) In the 9th Five-year Plan (1996-2000), 863 programme received USD 60,000 and 973 programme received USD 4.75 million for research funding.

(2) In the 10th Five-year Plan (2001-2005), a total of USD 8.23 million was invested for the development of hydrogen production from solar energy. USD 139 million was invested by the Ministry of Science and Technology to develop hybrid-electric vehicles and FCVs. In this stage, most funding was allocated to hybrid-electric vehicle development. The previously mentioned 973 programme received USD 5.6 million in funding at Tsinghua University to boost research on production, storage and transport of hydrogen, as well as the fuel cell membranes and catalysts.

(3) The 11th Five-year Plan (2006-2010) focused on the development of hydrogen fuel cell technology and FCVs, receiving USD 28.88 million and USD 23.74 million respectively.

(4) The 12th Five-year Plan (2011-2015) involved government support of strong incentives to boost the sales market for New Energy Vehicles (NEVs), including both electric vehicles (EVs) and FCVs. However, the EV sales market is growing faster than that of FCVs. However, while the EV sales market is growing faster than that of FCVs, FCVs are projected to follow the trends of EV sales within several years. Further funding via the 863 programme was allocated to research projects on hydrogen fuel cells, totalling up to USD 15.8 million of funding in 2011. The 973 programme, on the other hand, received USD 11.1 million of funding to enhance the development of solid oxide fuel cells and platinum-free fuel cells.

(5) The 13th Five-year Plan (2016-2020) prioritises introducing hydrogen to strategic emerging sectors of the country. Chinese companies are encouraged to explore and apply hydrogen production technologies, storage and fuel cell applications. This will eventually boost the construction of hydrogen refueling stations countrywide, as demand for hydrogen increases over time, especially in the transportation sector. This is in parallel with preparing to leverage China's FCV production capabilities.

The latest 13th Five year Plan (2016-2020) is believed to be the biggest game-changer for hydrogen development in China (Holland Innovation Network, 2018). Despite there being no specific targets set, the Chinese government has raised the issue of hydrogen technology development towards the country's strategic emerging sector and made clear that there are necessary accomplishments to reach in this Five-year Plan. This includes the research and development to improve FCV performance and find solutions to cut the cost of fuel cell stacks, in-depth research on technologies to enhance air compressors, hydrogen circulation pumps and other related systems and technologies, and the upgrade and improvement of fuel cell technology, FCV engines, and hydrogen storage and transport technology. Construction of hydrogen refueling stations should be boosted to keep up with the increasing demand of hydrogen. Strict standards are to be set up, such as the specific pressure for hydrogen cylinders in on-board storage systems. With all of these goals, the continuing and rapid development of hydrogen applications in China, specifically its transportation sector, can be projected. These efforts will have constructive impacts on not only vehicle manufacturing but various industries, as well as town and city governments, research institutions and end users.

Hydrogen technology is also part of the abovementioned Made in China 2025 plan, which aims at taking the Chinese manufacturing industry to leading-edge global competitiveness. It is included in part of the New Energy Vehicles section. The plan pinpointed specific technologies to be improved, such as catalytic materials, membranes and electrodes, interconnectors, vehicle lifetime and strategic industrialisation plans. Indeed, it is also in parallel with the country's Five-year Plan. The government has come up with the Technology Roadmap for Hydrogen Fuel Cell Vehicles, which establishes comprehensive plans for the construction of hydrogen refueling stations and FCV production through 2030. Hydrogen technology development is also under the support of various government plans such as the Energy Development Strategy Action Plan and the Energy Innovation Action Plan.

The Chinese Ministry of Science and Technology has also been working with the United Nations Development Programme (UNDP), to commercialise the use of fuel cell buses, known as the UNDP-GEF-MOST Project. It has been ongoing since 2003, initially involving the first phase of the project on planning, development and further demonstration projects of FCVs as mentioned in the previous sections. The project involves multiple 
partnerships with local governments and also vehicle manufacturing companies such as SAIC Motor, Foton and Daimler Chrysler. The second phase of the project involves the vehicle improvement strategies. The third phase of the project, which started in 2016, is named "Accelerating the Development and Commercialisation of Fuel Cell Vehicles in China", and is designed to tackle issues such as lagging FCV technologies, hydrogen production, transportation and refueling infrastructures, policy and legal framework, various stakeholder's engagement and public awareness (Ministry of Science and Technology of the People's Republic of China, 2016). Public awareness of hydrogen technology has been an issue in China, as doubt has been cast on the safety of FCVs, hydrogen production facilities, storage and transportation facilities. Therefore, the government has further work to do on various research and projects to ensure the maximum safety standards for hydrogen technology are met and to develop strategies to address it with the community.

The third phase of the project involves five demonstration cities: Beijing, Shanghai, Zhengzhou, Foshan and Yancheng (Ministry of Science and Technology of the People's Republic of China, 2016). Each city has its own steering committee for the project and its own project management office (PMO). The PMOs are responsible for following up with the progress made in the city and pointing out issues faced in their city, which will be discussed for further solutions. These cities are indeed considered pilot projects, and have been analysed and studied for further development in establishing future hydrogen cities in China. This project also involves the Hydrogen Economy Pilot Project in the city of Rugao (United Nations Development Programme (UNDP), 2016). The pilot project will take place to study a small-scale hydrogen economy in China and assess various perspectives, such as hydrogen production, transportation, policy making, public awareness and economic model design. At one point, hydrogen technology was tested in carbon trading schemes in the Rugao Economic and Technological Development zone. As Rugao is strategically located in the Yangtze River Delta region, the pilot project serves as a basis towards future development in implementing hydrogen infrastructure in other cities in the region.

Based on the information above, China's Ministry of Science and Technology is playing a key role in the hydrogen technology development in China. In terms of international alliances, China is part of the IPHE, which supports countries in the facilitation and acceleration in developing and implementing hydrogen and fuel cell technology in various sectors of the country, promoting the movement towards clean and energy efficient systems. It is also part of the International Hydrogen Fuel Cell Association (IHFCA), which is also involved in the development of hydrogen refueling stations and FCV manufacturing in China, whilst observing its standards and regulatory systems. Domestically, there are also alliances that support the development of hydrogen technology in various aspects and sectors such as the China Hydrogen Alliance, Hydrogen Industrial Technology Innovation Alliance of China (HITIAC) and Shenzhen Hydrogen and Fuel Cell Association.

Apart from the central government and ministries, as mentioned above, local governments are also supporting the development of hydrogen in their respective regions, with their owned tailored strategies and planning. These include setting up targets for the construction of hydrogen refueling stations and FCV production in the coming future, performing technology research and development projects, formulating industrial development strategies, policy making, establishing hydrogen prices, setting technical standards and regulations, and planning for purchase subsidies and various incentive programme to be implemented. These described strategies are similar to the approach of EVs in China few years ago, which eventually turned China into the country with the largest EV population in the world.

Overall, China has shown promising rapid development plans for the implementation of hydrogen technology, which is mainly focused in transportation sectors. They have been able to strategise their development plans in various programmes in parallel, perform crossprogramme partnership, and integrate hydrogen technology from the transportation sector as its basic defined structure towards various business and service sectors. With such varied programmes offering different perspectives, this has allowed China to understand the success and failures of each programme, providing China with a bank of knowledge and technical expertise on hydrogen technology that is essential as it steers towards future hydrogen technology-related developments and projects.

\subsubsection{Discussion on future development of clean hydrogen production}

As mentioned above, China is still relying on its coal-based steam methane reforming method to produce hydrogen, with electrolysis only accounting for $3 \%$ of hydrogen production. Production of clean hydrogen that seeks energy from renewable sources to power the electrolysis process will definitely help to ease China's reliance on coal and mitigate its carbon emissions. A country's renewable energy resources (RES) endowment is defined by its combined generation of potential solar and wind power (de Blasio and Pflugmann, 2020). RES endowment is affected by issues such as space constraints and other factors that affect the construction of renewable energy infrastructure. RES endowment is abundant only if a country's renewable energy generation is higher than its domestic primary energy consumption by approximately 5\%. China's RES potential is around 98.2 PWh and its primary energy consumption is around $34.8 \mathrm{PWh}$ (de Blasio and Pflugmann, 2020). 


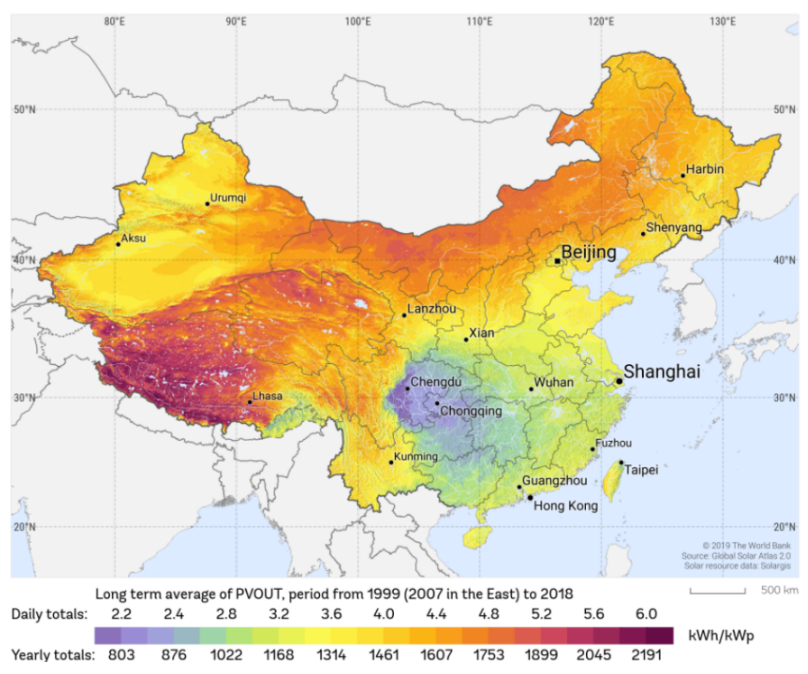

Figure 4. China's annual solar photovoltaic potential (Global Solar Atlas, 2020).

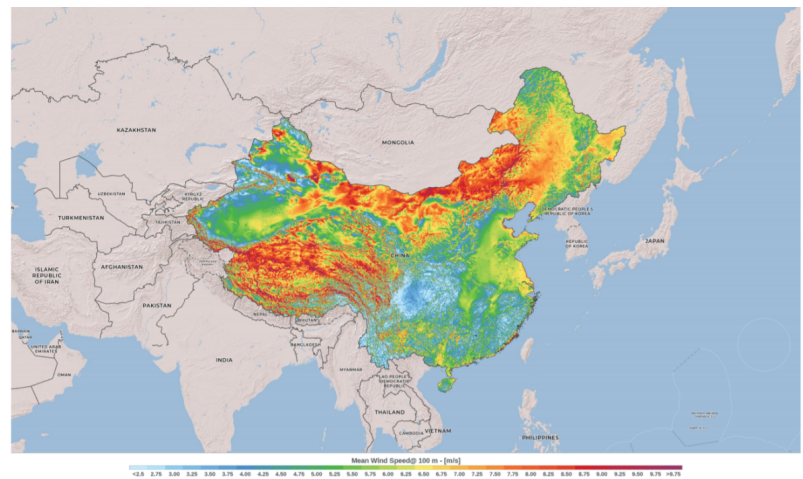

Figure 5. China's mean annual wind speed analysis (Global Wind Atlas, 2020).

Figures 4 and 5 show that China's southwestern and northern regions offer higher RES potential. The other factor that affects China's ability to produce clean hydrogen would be the availability of fresh water. Although China is not lacking in water as a country, the availability of fresh water varies by region. According to CWR (China Water Risk, 2017), water constraints are occurring in eastern parts of China, the country's main economic and industrial regions, meaning that hydrogen demand is higher in these regions. This creates an issue where the limited availability of fresh water affects the clean production of hydrogen, as water is the key input in this process. Seeing this issue, several developments have been proposed. Firstly, the RES endowment shall not be restricted to solar and wind energy, but shall also take into account hydropower. China is a major user and developer of hydropower, which accounts for $17 \%$ of electricity generated in the country, and approximately 1302 TWh of energy generated in 2019 (International Hydropower Association (IHA), 2020). Hydropower can also be a medium to produce renewable energy to power the electrolysis process. At the same time, fresh water used to power hydropower can also serve as a feedstock for the electrolysis process. With this, water scarcity may not be an issue in some southern and eastern regions such as Fujian, Zhejiang and Jiangxi provinces, making hydrogen productions in these regions a viable possibility.

Even with issues of water scarcity in the economic and industrial regions of China, the country may still formulate strategies to further research and develop hydrogen storage and transportation methods to ensure a smooth, efficient and safe domestic hydrogen supply chain.

\subsection{Japan}

Japan is one of the world's pioneering countries in the development and application of hydrogen technology. The hydrogen development strategy of Japan focuses on the implementation of hydrogen in the transportation sector, which includes FCVs, buses and forklifts using hydrogen technology. Research and development is still ongoing for power generation that utilises hydrogen. As of 2017, the hydrogen production volume in Japan is at 200 tonnes/ year with a cost of $\$ 10 / \mathrm{kg}$ (Ministry of Economy Trade and Industry (METI), 2017).

According to Japan's Ministry of Economy, Trade and Industry (METI), Japan is known to be a leader in hydrogen technology development. This technological development is motivated by Japan's current state of energy supply and demand. In terms of energy security, as of 2017, Japan depends heavily on fossil fuel imports that account for $94 \%$ of its primary energy supply, with oil-based fuels making up $98 \%$ of automobile fuels (Ministry of Economy Trade and Industry (METI), 2017). In terms of energy selfsufficiency, Japan has been stagnant at a rate of $6-7 \%$, the second lowest position out of 34 OECD countries, due to the closure of nuclear power plants following the 2011 Japan Earthquake. Per the Paris Agreement in 2016, Japan aims to reduce GHG emissions by $80 \%$ by 2050 . With this background, METI has designed Japan's Basic Hydrogen Strategy, which can be found in the references (Ministry of Economy Trade and Industry (METI), 2017). This strategy plays a key role in determining Japan's future plans for developing and implementing hydrogen technologies in their economy, as well as setting future targets to achieve.

In light of the current state of energy supply and demand in Japan, the utilisation of hydrogen will play as a significant role in maximising the country's energy supply. The variety of hydrogen production, storage, transportation and usage method is a way to diversify Japan's energy supply system, improving Japan's energy security by reducing dependence on a specific energy source. As hydrogen is emission-free, it supports Japan's commitment to reducing GHG emissions as mentioned in their goals in the 2016 Paris Agreement. Hydrogen energy utilisation supports Japan's energy objectives of " $3 \mathrm{E}+\mathrm{S}$ ", which focus on the nation's energy policy, emphasising energy 
security, economic efficiency, and environmental protection without compromising safety (Ministry of Economy Trade and Industry (METI), 2017). Japan aims to be a leader in reducing global carbon emissions by expanding technology and innovation to overseas, as well as realising hydrogen initiatives. Embedding hydrogen technology into industries will make industry growth more competitive.

The New Energy and Industrial Technology Development Organisation (NEDO) is Japan's largest public management organisation, promoting research developments and their application towards industrial, energy and environmental technologies. Currently, NEDO has three projects related to the utilisation and development of hydrogen.

(1) Development of Technologies for Hydrogen Refueling Stations is a project by NEDO which aims to achieve quick global dissemination of FCVs through research and development related to ultrahigh pressure hydrogen technology (New Energy and Industrial Technology Development Organisation (NEDO), 2020). The timeline for this project is the financial years of 2018-2022, with a budget of JPY 2.99 billion as of 2019. Goals include the development of technology for safe and affordable manufacturing, storing and logistics of hydrogen at a pressure of approximately 1,000 times more than atmospheric pressure, and its implementation in applications such as hydrogen refueling stations. Advancements in handling high pressure are believed to hold the key in promoting the popularity of FCVs as well. Technological development will contribute towards the promotion of regulatory reviews based on the Regulatory Reform Implementation Plan of Japan, as well as towards minimising the maintenance and operational costs of the hydrogen refueling stations. This project also aims to develop regulations, international standardisation, and quality control for high-pressure hydrogen tanks for vehicles and hydrogen-refueling. The research project can be summarised to these points:

(i) Technological development in optimising domestic regulations;

(ii) Technological development in cost reduction for hydrogen refueling stations; and

(iii) Research and development in international expansion and standardisation.

(2) Developing technologies to realise a hydrogen society will widen the application of hydrogen in the power generation sector, which supports Japan's goal of becoming the world's first fullscale hydrogen supply chain by 2030 . This is to ensure energy supply flexibility and energy security. This project ran through the financial years of 2014-2020, with budget of JPY 19.04 billion as of 2019 (New Energy and Industrial Technology Development Organisation (NEDO), 2020), and covers the following:

(i) Developing hydrogen energy system technology to supply stable energy with further research on using renewable energy to produce hydrogen, and development in terms of transportation, storage and utilisation;

(ii) Developing the utilisation of large-scale hydrogen energy technology from an integrated hydrogen supply chain system, from the production stage up through utilisation. Interestingly, this development process also involves utilising unused resources from overseas to produce hydrogen; and

(iii) A comprehensive approach in investigation and research on hydrogen energy-related policies in Japan and overseas. This is to maximise future prospects, organisation, systemisation and technologies through various approaches.

(3) The project on advancement of hydrogen technologies and utilisation is to lay a foundation for promotion of hydrogen as an option in a carbon-free energy approach. The project will focus on the comprehensive research and development of technologies in terms of high efficiency and low-cost hydrogen production from renewable energy, long journey transportation of hydrogen, energy carriers that support long-term storage of hydrogen and the large-scale application of hydrogen. This project is running through the financial years 2014 to 2022, with a budget of JPY 1.4 billion as of 2019 (New Energy and Industrial Technology Development Organisation (NEDO), 2020). The research and development to be focused on in this project include:

(i) Basic technology in enhancing waterelectrolysis hydrogen technology

(ii) Utilisation of hydrogen in large scale technology

(iii) Basic technology in ultrahigh efficient power generation systems

(iv) Surveying of energy-carrier systems

(v) Surveying of carbon-free hydrogen production technologies such as hydrocarbon technology

According to the Financial Times, at the present hydrogen is produced mainly as a by-product of the chemical industry, in which the process also emits carbon dioxide at the same time (Harding, 2020). An alternative process is the electrolysis of water, although if the electricity is sourced from an electric/conventional power plant which emits carbon dioxide, the carbon emissions 
may be considered comparable. The Ministry of Economy, Trade and Industry is currently developing an expansive development programme to gasify Australian brown coal for use in producing more affordable hydrogen. At the same time, carbon emissions will be regulated using carbon capture storage (CCS). This hydrogen produced in Australia will be transported to Japan using tankers and further distributed to various filling stations across the country to reach the end user.

\subsection{South Korea}

South Korea is another pioneering country in Asia in terms of hydrogen application. It has taken credit as the first country to launch commercial hydrogen fuel cell vehicles (FCV) to the market, namely the Hyundai Tucson ix35 model in 2013, despite Japan's earlier efforts to lead in hydrogen-powered vehicle development. From an industrial perspective, South Korea's POSCO Energy, the country's largest private energy producer, completed the world's largest fuel cell manufacturing plant in 2015 (Sichao, 2018).

Currently, South Korea's priority for hydrogen development is to become the pioneer in fuel cell vehicles and large-scale stationary fuel cells used for power generation. According to the Netherlands Enterprise Agency, which took part in reviewing South Korea's Hydrogen Economy Plan, hydrogen will play a role in its economic development as a solution for a few challenges (Ha, 2019). The South Korean government aims to solve the elaborate societal problems by further developing a national scale hydrogen economy, while at the same time integrating the two main industries of South Korea, the semiconductor and automotive industries. Thus, the development of a hydrogen economy in the country could have a positive impact from both an economical and environmental perspective.

In 2018, President Moon of South Korea announced a plan to leverage hydrogen's capability as a new growth engine to push the country towards a hydrogen economy (Sichao, 2018). The Ministry of Trade, Industry and Energy announced the allocation of 2.6 trillion KRW in 2018 to establish a public-private hydrogen vehicle industry ecosystem to be completed by 2022. In 2019, the South Korean government released the Hydrogen Economy Roadmap of Korea and the National Roadmap of Hydrogen Technology Development, which established long-term development goals through 2040 (Ministry of Trade, Industry and Energy, 2019). In January 2020, the National Assembly passed the "Hydrogen Law"-more accurately, the Hydrogen Economy Promotion and Hydrogen Safety Management Law-which acts as the legal foundation for the government's continuous support towards the development of hydrogen and its safety standards to be implemented in designated facilities (Sichao, 2018; Korean Law Information Center, 2020)
In terms of policy and financial assistance, the central and local governments of South Korea provided a combined subsidy to support FCV purchases at a total cost of KRW 32.5-36 million in 2019, equivalent to USD 27,300-30,000 (Sichao, 2018). This subsidy is almost half the price of a Hyundai NEXO FCV model, which costs around KRW 70 million (USD 59,000). This prompted the sale of 4,194 units of the 2019 Hyundai NEXO as of 2019 (Hyundai Motor Company, 2019).

As of December 2020, South Korea has 52 operating hydrogen refueling stations, 27 hydrogen-powered buses and 10,041 FCVs on the road (IPHE, 2020). In March 2019, the South Korean Central Government, along with 13 other companies, established the Hydrogen Energy Network (HyNet), a company that specialises in the development of hydrogen refueling stations and aims to build 100 stations by 2022 (Sichao, 2018). By 2020, the government had subsidised about half of these hydrogen refueling stations. In terms of FCVs on the road, the President of South Korea's new official car is a Hyundai NEXO SUV (Lee, 2019). By making an FCV the official vehicle of the nation's leader, public awareness was raised about FCVs and hydrogen technology, the benefits to the environment, economy, energy and society, and its uncompromised safety. Despite this, the VP of Hyundai Motor's fuel cell business group, Simon Park, mentioned that South Korea's fuel cell drive is a step behind in market penetration, and should be strengthened via government subsidies (Hosokawa, 2019).

In terms of hydrogen production, South Korea is currently using hydrogen produced as a by-product of petrochemical plants, as well as using a natural gas reforming method without carbon capture storage (CCS) (Sichao, 2018). Projects such as the Hydrogen Town Project demonstration in Ulsan have been in place since 2012 to foster partnerships with local corporates to build more hydrogen production facilities based on petrochemical byproducts or natural gas reforming. With the government's plans to develop a hydrogen economy, their main goal is to ensure that the future growing demand of hydrogen can be met. Beyond than local hydrogen production, South Korea has also partnered with Norway and Australia for future feasible hydrogen imports.

The explosion of a hydrogen storage tank in 2019 has made the citizens question the safety of hydrogen as an energy source, especially for FCVs. With these safety concerns in mind, the South Korean government continues to develop a hydrogen society, and continues to work with other parties, especially car manufacturers such as Hyundai, on various strategies to fulfil its hydrogen roadmap and other hydrogen-related development plans. Currently, the issues faced in South Korea include infrastructure, cost and safety aspects of hydrogen FCVs, refueling stations and other facilities in the hydrogen supply chain. The government and society look on these challenges positively. 


\section{Conclusion and Outlook}

The development of hydrogen technology in the APEC economies of China, Japan and South Korea is in relatively early stages. However, strong initiatives can be seen in these countries owing to their current national strengths and their tailored national strategies and approaches. Indeed, hydrogen technology has become a common key towards the future of cleaner energy that can support emission reductions.

China, being the largest producer of hydrogen in the world, is also taking a leading role in hydrogen development. As other economies are exploring and researching methods to develop clean hydrogen from an electrolysis process powered by renewable energy sources, China prioritises the applications of hydrogen technology. The applications would include implementation of hydrogen technology in transportation sectors and as a reserve energy source for their booming renewable energy developments, to ensure that demand levels are being met. Hydrogen technological development is embedded in various plans of the government, including the Made in China 2025 initiative, which is designed to boost its manufacturing sector. It is also part of China's ambitions towards being a technological powerhouse and its contribution towards combating climate change. To date, hydrogen technology has been mostly implemented in China's transportation sector and has become the backbone of China's hydrogen development strategy. They have been successful in terms of integrating various sectors and industries linked to the transportation sector for the development of hydrogen technology.

Japan's approach towards hydrogen development includes the transportation sector and aims to reach power generation capacity in the future, eventually developing a hydrogen society. It is one of Japan's strategies towards diversifying its energy sources, reducing their dependency on a specific energy source, and thus maximising the country's energy security. With hydrogen being emissionfree, it can further support Japan's goal towards reducing its emissions overall. Japan also aims to not only implement hydrogen technology towards their own industry and economy, but also to export their technology to overseas. It can ensure Japan's “ $3 E+S$ " energy objective which focuses on energy security, energy policy, economic efficiency and the environment without compromising its safety standards.

Similarly, South Korea also takes an approach towards being a pioneer in FCVs and hydrogen technology for power generation. South Korea has its own Hydrogen Economy Plan, which ensures hydrogen's place in the future economic development plan of the country. With the ambitious plan of building a hydrogen economy, South Korea hopes that the development of hydrogen technology can support the economy, environment and the society's well-being. The South Korean government has also been supportive towards the development of hydrogen technology, especially in terms of policy, financial support and the development of safety codes and standards.

Table 3 below serves as a summary of references on the hydrogen being produced currently in China, Japan and South Korea, to support their hydrogen technology applications, as well as future plans on the development of hydrogen technology.

Table 3. Summary of hydrogen production and further plans.

\begin{tabular}{|c|c|c|c|}
\hline & Source & Method & Further plans \\
\hline China & - Local & $\begin{array}{l}\text { - Coal-based SMR } \\
\text { - Electrolysis }\end{array}$ & $\begin{array}{l}\text { - Continue developing } \\
\text { hydrogen applications for } \\
\text { transportation } \\
\text { - Hydrogen as reserve energy } \\
\text { source for booming renewable } \\
\text { energy developments } \\
\text { - Boost technological } \\
\text { development for future } \\
\text { domestic and export } \\
\text { opportunities }\end{array}$ \\
\hline Japan & $\begin{array}{l}\text { - Local } \\
\text { - Import }\end{array}$ & $\begin{array}{l}\text { - Coal-based SMR } \\
\text { - Electrolysis } \\
\text { - By-product } \\
\text { of industrial } \\
\text { operations }\end{array}$ & $\begin{array}{l}\text { - Realising future hydrogen } \\
\text { society } \\
\text { - Future technology export } \\
\text { opportunities } \\
\text { - Implementing hydrogen for } \\
\text { power generation and FCV } \\
\text { development } \\
\text { - Strategic partnership with } \\
\text { Australia for continuous } \\
\text { hydrogen imports and } \\
\text { development }\end{array}$ \\
\hline $\begin{array}{l}\text { South } \\
\text { Korea }\end{array}$ & - Local & $\begin{array}{l}\text { - Natural Gas } \\
\text { Reforming } \\
\text { - By-product } \\
\text { of industrial } \\
\text { operations }\end{array}$ & $\begin{array}{l}\text { - Policy and financial support } \\
\text { to ensure robust development } \\
\text { - Realising future hydrogen } \\
\text { economy } \\
\text { - Implementing hydrogen for } \\
\text { power generation and FCV } \\
\text { development } \\
\text { - Future hydrogen import from } \\
\text { Australia and Norway to } \\
\text { ensure supply for growing } \\
\text { demand }\end{array}$ \\
\hline
\end{tabular}

*SMR = steam methane reforming

Overall, the initial stages of hydrogen development in these East Asian countries within the APEC region have been regarded as encouraging. The efforts of the economies have made them ready for future developments in hydrogen technology. Indeed, these efforts can serve as a great example for the potential of hydrogen technology development by other APEC economies and a call to take part in the development of hydrogen technology. Eventually, hydrogen technology may become the global move towards a sustainable collective energy, with economic, environmental and social developments in the future. 


\section{Acknowledgments}

The review work presented in this paper was supported by Hong Kong Research Grant Council (RGC) GRF1305419 project and the General Programme of Science and Technology Innovation Committee of Shenzhen Municipality (JCY20190808181805621).

\section{Notes on Contributors}

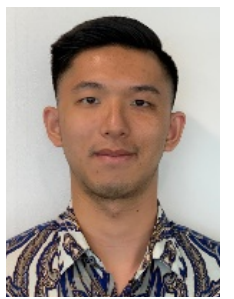

Mr Pradipto Suwidji is a recent graduate from the School of Energy and Environment, City University of Hong Kong. He pursued his BEng degree in Energy Science and Engineering. He has spent one year at Dr. Ng's laboratory studying the emerging technology on hydrogen development, production, transportation and application.

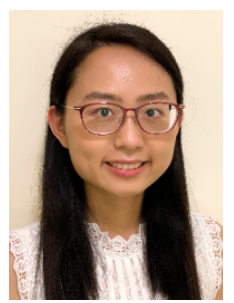

Dr Hoi Ying Chung received her B.S. and Ph.D. degree in Chemical Engineering from the University of New South Wales, Australia, in 2019. At present, she works at the City University of Hong Kong. Her current research concentrates on developing and improving photoactive semiconductors (particles and thin film) for conversion of solar energy into chemical fuels.

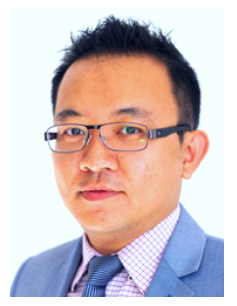

Dr Yun Hau Ng received his Ph.D. from Osaka University, Japan, in 2009. He is currently an associate professor in the School of Energy and Environment, City University of Hong Kong. His research is focused on the development of hydrogen technology using novel photoactive semiconductors for sunlight energy conversion. He received the Honda-Fujishima Prize in 2013, Distinguished Lectureship Award from the Chemical Society of Japan in 2018, and APEC ASPIRE Prize in 2019 on his research in artificial photosynthesis.

\section{References}

[1] ACIL Allen Consulting (2020). OPPORTUNITIES FOR AUSTRALIA FROM HYDROGEN EXPORTS. [PDF]. Available at: <https://arena.gov.au/ assets/2018/08/opportunities-for-australia-fromhydrogen-exports.pdf $>$. [Accessed on 11 January 20210].
[2] Air Liquide (2018). China: Air Liquide and the startup STNE sign an agreement for the development of hydrogen mobility. [Online]. Available at: <https:// www.airliquide.com/china/china-air-liquide-andstartup-stne-sign-agreement-development-hydrogenmobility $>$. [Accessed on 13 January 2021].

[3] Ballard Power (2020). Gaoming Line to be World's First Fuel Cell-Powered Commercial Tram System. [Online]. Available at: <https://www.ballard. com/about-ballard/newsroom/market-updates/ gaoming-line-to-be-world-s-first-fuel-cell-poweredcommercial-tram-system\#: :text=Gaoming $\% 20$ Line $\% 20$ to $\% 20$ be $\% 20$ World's, fue $1 \% 20$ cell $\% 2$ Dpowered $\% 20$ tram $\% 20$ operation>. [Accessed on 13 January 2021].

[4] Ballard Power (2020). Tangshan Railway Vehicle Company Commences Hydrogen Powered Tram Trial. [Online]. Available at: <https://www.ballard.com/ about-ballard/newsroom/market-updates/tangshanrailway-vehicle-company-commences-hydrogenpowered-tram-trial $>$. [Accessed on 13 January 2021].

[5] Bermudez J and Hasegawa T (2020). Hydrogen Analysis. Paris: International Energy Agency (IEA). Available at: <https://www.iea.org/reports/hydrogen>. [Accessed on 12 January 2021].

[6] Brauns J and Turek T (2020). Alkaline Water Electrolysis Powered by Renewable Energy: A Review. Processes, 8(2), 248. Available at: <http:// dx.doi.org/10.3390/pr8020248>. [Accessed on 12 January 2021].

[7] China Water Risk (2017). Who's Running Dry Major cities \& provinces - China Water Risk. [Online] Available at: $<$ https://www.chinawaterrisk.org/the-bigpicture/whos-running-dry/>. [Accessed on 14 January 2021]]

[8] de Blasio N and Pflugmann F (2020). Is China's Hydrogen Economy Coming?. [PDF]. Cambridge, MA: Belfer Center for Science and International Affairs. Available at: $<$ https://www.belfercenter. $\mathrm{org} / \mathrm{sites} / \mathrm{default} /$ files/files/publication/Is $\% 20$ China $\% 27 \mathrm{~s} \% 20$ Hydrogen $\% 20$ Economy $\% 20$ Coming\%207.28.20.pdf $>$. [Accessed on 12 January 2021].

[9] Global Solar Atlas (2020). China. [Online]. Available at: <https://globalsolaratlas.info/download/china $>$. [Accessed on 14 January 2021].

[10] Global Wind Atlas (2020). China. [Online]. Available at: $<$ https://globalwindatlas.info/en/area/ China?print=true $>$. [Accessed on 14 January 2021].

[11] Ha E J (2019). Hydrogen Economy Plan in Korea. [PDF]. Available at : <https://www.rvo.nl/sites/ default/files/2019/03/Hydrogen-economy-plan-inKorea.pdf $>$. [Accessed on 15 January 2021]. 
[12] Harding R (2020). Japan's hydrogen dream: gamechanger or a lot of hot air? Financial Times. [Online]. Available at : <https://www.ft.com/content/c586475e7260-11e9-bf5c-6eeb837566c5>. [Accessed on 15 January 2021].

[13] Holland Innovation Network. (2019). Overview of hydrogen and fuel cell developments in China. [PDF] Shanghai: Holland Innovation Network. Available at : <https://www.nederlandwereldwijd. $\mathrm{nl} /$ binaries/nederlandwereldwijd/documenten/ publicaties/2019/03/01/waterstof-in-china/Holland+In novation+Network+in+China +-+ Hydrogen+develop ments. + January+2019.pdf $>$. [Accessed on 12 January 2021].

[14] Hosokawa K (2019). South Korea targets hydrogen economy, from cars to cities. [Online]. Available at: $<$ https://asia.nikkei.com/Business/Business-trends/ South-Korea-targets-hydrogen-economy-from-carsto-cities $>$. [Accessed on 17 January 2021].

[15] Hyundai Motor Company (2019). Sales Performance. [Online]. Available at: <https://www.hyundai. com/worldwide/en/company/ir/ir-activities/salesperformance $>$. [Accessed on 16 January 2021].

[16] International Energy Agency. (2019). The Future of Hydrogen - Analysis. Paris: International Energy Agency (IEA). Available at: $<$ https://www.iea.org/ reports/the-future-of-hydrogen $>$. [Accessed on 12 January 2021].

[17] International Energy Agency (2015). Technology Roadmap - Hydrogen and Fuel Cells. Paris: International Energy Agency (IEA). Available at: $<$ https://www.iea.org/reports/technology-roadmaphydrogen-and-fuel-cells $>$ [Accessed on 11 January 2021].

[18] International Hydropower Association (IHA) (2020). China. [Online] Available at: <https:// www.hydropower.org/country-profiles/ china\#: : text $=$ According\%20to $\% 20$ IHA's $\% 20$ $2020 \% 20$ Hydropower,temporary $\% 20$ pause $\% 20$ on $\% 20$ new\%20projects $>$. [Accessed on 14 January 2021].

[19] IPHE (2020). China. [Online]. Available at: <https:// www.iphe.net/china $>$. [Accessed on 13 January 2021].

[20] IPHE (2020). Republic of Korea. [Online]. Available at: <https://www.iphe.net/republic-of-korea $>$. [Accessed on 17 January 2021].

[21] JD Corporate Blog (2018). New Hydrogen-Powered JD.com Delivery Trucks Emit Only Purified Water.

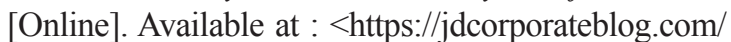
new-hydrogen-powered-jd-com-delivery-trucksemit-only-purified-water/>. [Accessed on 13 January 2021].
[22] Jiang Y, Bowei Z, Wang F and Liu M (2020). Research on Hydrogen Energy and Fuel Cell Vehicle Roadmap in Various Countries. IOP Conference Series: Earth And Environmental Science, 512(012136). Available at: $<$ http://doi.org/10.1088/1755-1315/512/1/012136>. [Accessed on 13 January 2021].

[23] Kan S (2018). South Korea's Hydrogen Strategy and Industrial Perspective. [PDF]. Paris: Edito Energie, Ifri. Available at : < https://www.ifri.org/en/ publications/editoriaux-de-lifri/edito-energie/southkoreas-hydrogen-strategy-and-industrial $>$. [Accessed on 15 January 2021].

[24] Korean Law Information Center (2020). Hydrogen Economy Promotion and Hydrogen Safety Management Act. [Online]. Available at : $<\mathrm{https}: / /$ www.law.go.kr $\%$ EB $\% \mathrm{~B} 2 \% 95 \% \mathrm{~EB} \% \mathrm{~A} 0 \% \mathrm{~B} 9 / \% \mathrm{EC}$ $\% 88 \% 98 \% \mathrm{EC} \% 86 \% 8 \mathrm{C} \% \mathrm{EA} \% \mathrm{~B} 2 \% \mathrm{BD} \% \mathrm{EC} \% \mathrm{~A} 0 \%$ 9C $\%$ EC $\% 9 \mathrm{C} \% \mathrm{~A} 1 \% \mathrm{EC} \% 84 \% \mathrm{~B} 1 \% \mathrm{~EB} \% \mathrm{~B} 0 \% 8 \mathrm{~F} \% \mathrm{E}$ C $\% 88 \% 98 \% \mathrm{EC} \% 86 \% 8 \mathrm{C} \% \mathrm{EC} \% 95 \% 88 \% \mathrm{EC} \% \mathrm{~A} 0 \%$ $84 \%$ EA $\%$ B $\% 80 \%$ EB $\%$ A6\%AC $\%$ EC $\% 97 \% 90 \%$ EA $\%$ B $\% 80 \%$ ED $\% 95 \% 9 \mathrm{C} \%$ EB $\%$ B $\% 95 \%$ EB $\%$ A5 $\% \mathrm{~A} 0 /(16942,20200204)>$. [Accessed on 16 January 2021].

[25] Lee C (2019). (LEAD) Moon's presidential hydrogen car debuts amid his clean energy drive. Yonhap News Agency. [Online]. Available at: $<$ https://en.yna.co.kr/ view/AEN20190827007551315>. [Accessed on 17 January 2021].

[26] Liu Z, Kendall K and Yan X (2018). China Progress on Renewable Energy Vehicles: Fuel Cells, Hydrogen and Battery Hybrid Vehicles. Energies, 12(54). Available at: < https://doi.org/10.3390/en12010054>. [Accessed on 13 January 2021].

[27] Ministry of Economy Trade and Industry (METI) (2017). Basic Hydrogen Strategy (Key Points). [PDF]. Available at: $<$ https://www.meti.go.jp/english/ press/2017/pdf/1226_003a.pdf>. [Accessed on 14 January 2021].

[28] Ministry of Economy Trade and Industry (METI) (2017). Basic Hydrogen Strategy (Full Text). [PDF]. Available at: <https://www.meti.go.jp/english/ press/2017/pdf/1226_003b.pdf $>$. [Accessed on 14 January 2021].

[29] Ministry of Science and Technology of the People's Republic of China (2016). MOST/GEF/ UNDP "Commercialization of Fuel Cell Vehicles in China" Project Launched. [Online] Available at: <http://en.most.gov.cn/eng/pressroom/201610/ t20161024_128303.htm>. [Accessed on 13 January 2021].

[30] Ministry of Trade, Industry and Energy (2019). Hydrogen Economy Roadmap of Korea. [PDF]. Available at: $<$ https://docs.wixstatic.com/ugd/45185a fc 2 f37727595437590891a3c7ca0d025.pdf $>$. [Accessed on 15 January 2021]. 
[31] New Energy and Industrial Technology Development Organisation (NEDO) (2020). Advancement of Hydrogen Technologies and Utilization Project. [Online]. Available at : <https://www.nedo.go.jp/ english/activities/activities_ZZJP_100068.html>. [Accessed on 14 January 2021].

[32] New Energy and Industrial Technology Development Organisation (NEDO) (2020). Development of Technologies for Hydrogen Refueling Stations. [PDF]. Available at : <https://www.nedo.go.jp/english/ activities/activities_ZZJP_100144.html $>$. [Accessed on 14 January 2021].

[33] New Energy and Industrial Technology Development Organisation (NEDO) (2020). Development of Technologies for Realizing a Hydrogen Society. [Online]. Available at : <https://www.nedo.go.jp/ english/activities/activities_ZZJP_100096.html>. [Accessed on 14 January 2021].

[34] Sichao K, Kimura K, and Ishida H, (2018). Perspectives on Hydrogen in the APEC Region. [PDF] Tokyo: Asia Pacific Energy Research Centre (APERC). Available at: <https://aperc.or.jp/ file/2018/9/12/Perspectives + on + Hydrogen + in + the + A PEC+Region.pdf $>$. [Accessed on 11 January 2021]

[35] Society of Automotive Engineers of China. Hydrogen Fuel Cell Vehicle Technology Roadmap. Translated from Chinese by AngloAmerican. [PDF]. Available at: <http://www.sae-china.org/download/1896/Hydro gen + Fuel + Cell + Vehicle + Technology + Roadmap $+\%$ E6\%B0\%A2\%E7\%87\%83\%E6\%96\%99\%E7\%94\% B5\%Е6\%B1\%A0\%Е6\%B1\%BD $\%$ E8\%BD\%A6\%Е $6 \% 8 \mathrm{~A} \% 80 \% \mathrm{E} 6 \% 9 \mathrm{C} \% \mathrm{AF} \% \mathrm{E} 8 \% \mathrm{~B} 7 \% \mathrm{AF} \% \mathrm{E} 7 \% \mathrm{BA}$ $\% \mathrm{BF} \% \mathrm{E} 5 \% 9 \mathrm{~B} \% \mathrm{BE} \cdot \mathrm{pdf}>$. [Accessed on 13 January 2021].

[36] United Nations Development Programme (UNDP) (2016). Hydrogen Economy Pilot in China (Rugao Project). [Online] Available at: $<$ https://www.cn.undp. org/content/china/en/home/operations/projects/ environment and energy/china-hydrogen-economypilot-in-rugao.html $>$. [Accessed on 14 January 2021].

[37] U.S Geological Survey (2020). Mineral Commodity Summaries 2020. [PDF]. Reston, VA: U.S. Geological Survey. Available at: < http://dx.doi.org/ 10.3133/ mcs2020>. [Accessed on 13 January 2021].

[38] Yue M and Wang C (2020). Hydrogen: China's Progress and Opportunities for a Green Belt and Road Initiative - Green Belt and Road Initiative Center. [Online]. Available at: <https://green-bri.org/ hydrogen-chinas-progress-and-opportunities-fora-green-belt-and-road-initiative $>$. [Accessed on 12 January 2021]. 